\title{
Is Slow-Onset Long-Acting Monoamine Transport Blockade to Cocaine as Methadone is to Heroin? Implication for Anti-Addiction Medications
}

\author{
Xiao-Qing Peng', Zheng-Xiong Xi*,', Xia Li', Krista Spiller', Jie Li', Lauren Chun', Kuo-Ming Wu', \\ Mark Froimowitz ${ }^{2,3}$ and Eliot L Gardner' \\ 'Intramural Research Program, National Institute on Drug Abuse, NIH, DHHS, Baltimore, MD, USA; ${ }^{2}$ Pharm-Eco Laboratories, Devens, MA, USA; \\ ${ }^{3}$ DNAPrint Pharmaceuticals, Sarasota, FL, USA
}

\begin{abstract}
The success of methadone in treating opiate addiction has suggested that long-acting agonist therapies may be similarly useful for treating cocaine addiction. Here, we examined this hypothesis, using the slow-onset long-acting monoamine reuptake inhibitor 31,345, a transaminotetralin analog, in a variety of addiction-related animal models, and compared it with methadone's effects on heroin's actions in the same animal models. Systemic administration of 31,345 produced long-lasting enhancement of electrical brain-stimulation reward (BSR) and extracellular nucleus accumbens (NAc) dopamine (DA). Pretreatment with 31,345 augmented cocaine-enhanced BSR, prolonged cocaine-enhanced NAc DA, and produced a long-term (24-48 h) reduction in cocaine self-administration rate without obvious extinction pattern, suggesting an additive effect of 31,345 with cocaine. In contrast, methadone pretreatment not only dose-dependently inhibited heroin self-administration with an extinction pattern but also dose-dependently inhibited heroin-enhanced BSR and NAc DA, suggesting functional antagonism by methadone of heroin's actions. In addition, 31,345 appears to possess significant abuse liability, as it produces dose-dependent enhancement of BSR and NAc DA, maintains a low rate of self-administration behavior, and dose-dependently reinstates drug-seeking behavior. In contrast, methadone only partially maintains self-administration with an extinction pattern, and fails to induce reinstatement of drug-seeking behavior. These findings suggest that 31,345 is a cocaine-like slow-onset long-acting monoamine transporter inhibitor that may act as an agonist therapy for cocaine addiction. However, its pattern of action appears to be significantly different from that of methadone. Ideal agonist substitutes for cocaine should fully emulate methadone's actions, that is, functionally antagonizing cocaine's action while blocking monoamine transporters to augment synaptic DA.

Neuropsychopharmacology (20I0) 35, 2564-2578; doi:I0. I038/npp.20 I0.133; published online 8 September 2010
\end{abstract}

Keywords: cocaine; addiction; heroin; methadone; 31,345; DA transporter

\section{INTRODUCTION}

Cocaine abuse is a severe public health problem, for which no effective pharmacotherapy exists. It is believed that cocaine's abuse potential derives from blockade of monoamine transporters, especially dopamine (DA) transporters (DAT), leading to an increase in extracellular nucleus accumbens (NAc) DA (Di Chiara, 1995; Wise, 1996). Given the success of long-acting agonist therapies, that is, methadone for opiate dependence (Dole and Nyswander, 1965; Dole et al, 1966; Kreek, 2000; Veilleux et al, 2010), and nicotine replacement therapy (NRT) for smoking cessation (Kozlowski et al, 2007; Fiore et al, 2008), it has been proposed that a monoamine transport or DAT inhibitor

*Correspondence: Dr Zheng-Xiong Xi, Intramural Research Program, National Institute on Drug Abuse, NIH, DHHS, Baltimore, MD 21224, USA, Tel: + I 443740 2517, Fax: + I 443740 278I, E-mail: zxi@intra.nida.nih.gov

Received 17 February 20 I0; revised 4 July 20 I0; accepted 27 July 2010 might similarly serve as an agonist therapy for cocaine and, thus, treat cocaine addiction (Rothman and Glowa, 1995; O’Brien, 1997). To date, many such monoamine transport or DAT inhibitors have been developed, and several of them (such as GBR12909, dextroamphetamine, and methylphenidate) have been tested for anti-addiction potential (Platt et al, 2002; Howell and Wilcox, 2001; Newman and Kulkarni, 2002; Grabowski et al, 2004; Runyon and Carroll, 2006; Rothman et al, 2008). However, none have proven successful - largely because of significant abuse liability by these compounds themselves and/or significant cardiovascular side effects.

Recently, DAT inhibitors with slow-onset, long-acting pharmacokinetic profiles have attracted attention. This is based on the finding that a drug's abuse liability is related to rate of onset and duration of action, that is, the quicker the onset and offset, the higher the abuse liability (Busto and Sellers, 1986; Oldendorf, 1992; Volkow et al, 1995; Woolverton and Wang, 2004). Also, electrical brainstimulation reward (BSR) with slow decay parameters is 


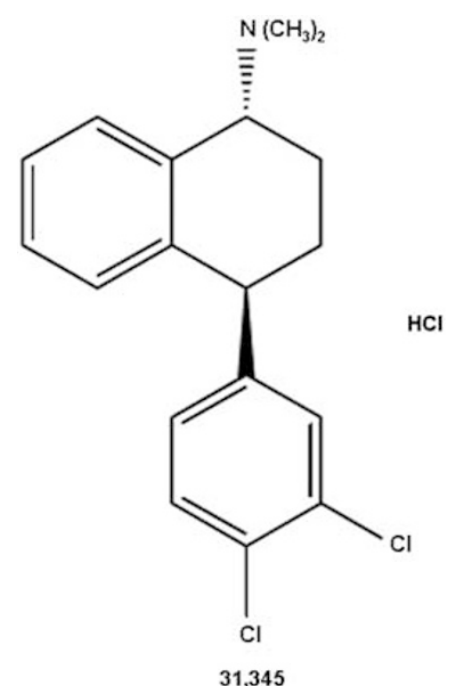

Figure I Chemical structure of compound 31,345.

less appetitive than BSR with fast decay parameters (Lepore and Franklin, 1992), suggesting that brain reward of equivalent efficacy loses appetitiveness when altered to have slow-onset/offset kinetics. Thus, a slow-onset, longacting DAT inhibitor might reduce cocaine abuse by substitution, while itself having low abuse potential. This is supported by the finding that GBR12909 decanoate ester, a slowly released DAT inhibitor, produces prolonged $(\sim 30$ day) suppression of cocaine self-administration in primates (Glowa et al, 1996). Recently, we have developed several chemical series of slow-onset long-acting monoamine transport inhibitors as candidate pharmacotherapies for treating cocaine addiction (Froimowitz et al, 2000, 2007). The indanamine compound, 30,640 , is one such candidate that significantly inhibits cocaine self-administration in rats (Gardner et al, 2006). However, 30,640 appears to have low therapeutic potential because of high psychomotor-stimulating effects and probable abuse liability (Gardner et al, 2006).

In this study, we evaluated the potential utility of the slow-onset long-acting monoamine transporter inhibitor 31,345, a trans-aminotetralin analog (Figure 1) (Welch et al, 1984), in animal models of cocaine addition. First, we characterized 31,345's pharmacological actions on BSR and NAc DA to determine whether it has the desired slow-onset long-acting DAT inhibitor profile. We then observed the effects of 31,345 on cocaine's actions on BSR and NAC DA, and on cocaine self-administration. To determine whether the effects of 31,345 on cocaine's actions are mediated by a mechanism similar to that of methadone on heroin's actions, we observed methadone's effects on heroin's actions in the same animal models. Finally, we investigated and compared abuse liability of 31,345 and methadone using a self-administration substitution procedure and a reinstatement of drug-seeking model.

\section{MATERIALS AND METHODS}

\section{Animals}

Male Long-Evans rats, initially weighing 250-300 g, were used for all experiments. They were housed individually in a climate-controlled animal colony room on a reversed light-dark cycle with free access to food and water. All experimental procedures were conducted in accordance with the Guide for the Care and Use of Laboratory Animals and were approved by the Animal Care and Use Committee of the National Institute on Drug Abuse of the US National Institutes of Health.

\section{Drugs and Chemicals}

Cocaine and heroin were provided by RTI International (Research Triangle Park, NC) and methadone was obtained from Sigma Chemical (Saint Louis, MO). Compound 31,345 (trans-[4-(3,4-dichlorophenyl)-1,2,3,4-tetrahydronaphthalen1-yl]dimethylammonium chloride) was synthesized at Pharm-Eco Laboratories, and dissolved in $25 \%$ or $5 \% 2$ hydroxypropyl- $\beta$-cyclodextrin for intraperitoneal (i.p.) or intravenous (i.v.) administration, respectively.

\section{Intracranial BSR}

The general procedures for electrical BSR were as we have reported previously (Xi et al, 2006; Spiller et al, 2008). Briefly, rats were anesthetized under sodium pentobarbital, and unilateral monopolar stainless-steel stimulating electrodes were surgically placed into the lateral hypothalamus (AP $-2.56, \mathrm{ML} \pm 1.9$, and $\mathrm{DV}-8.6$, according to the rat brain stereotaxic atlas of Paxinos and Watson, 1998). After 7 days of recovery from surgery, rats were allowed to self-train (autoshape) to lever press for BSR. After establishment of lever pressing for BSR, animals were presented with a series of 16 different pulse frequencies, ranging from 141 to $25 \mathrm{~Hz}$ in descending order. The BSR threshold $\left(\theta_{0}\right)$ was defined as the minimum frequency at which the animal responded for rewarding stimulation. Ymax was defined as the maximal rate of response. The BSR threshold $\left(\theta_{0}\right)$ and $Y \max$ were mathematically derived for each baseline run and each test run by analyzing each rate-frequency BSR function generated by a given animal over a given descending series of pulse frequencies using best-fit mathematical algorithms, as reported previously (Xi et al, 2006; Spiller et al, 2008).

Testing the effects of cocaine or 31,345 on BSR. Once a baseline $\theta_{0}$ value was achieved $(<15 \%$ variation over 3 continuous days), the effects of cocaine and/or 31,345 on BSR were assessed. On test days, animals randomly received one of three different doses of 31,345 (1, 5, or $10 \mathrm{mg} / \mathrm{kg}$, i.p.) or vehicle ( $1 \mathrm{ml}$ of $25 \%$ 2-hydroxypropyl- $\beta$-cyclodextrin) $30 \mathrm{~min}$ before a cocaine injection $(2 \mathrm{mg} / \mathrm{kg}$, i.p.). After each test, animals received an additional 5-7 days of BSR restabilization until a new baseline $\theta_{0}$ was established. The order of testing of various doses of 31,345 was counterbalanced. The effects of 31,345 alone on BSR or 31,345 pretreatment on cocaine-enhanced BSR were evaluated by comparing cocaine-induced alterations in $\theta_{0}$ value in the presence or absence of each dose of 31,345 .

Testing the effects of heroin and/or methadone on BSR. In a similar way, two additional groups of rats were used to evaluate the effects of methadone $(1,3,5$, and $8 \mathrm{mg} / \mathrm{kg})$ alone on BSR and of methadone pretreatment on heroin $(0.1,0.2$, and $0.3 \mathrm{mg} / \mathrm{kg})$-enhanced BSR. 


\section{In Vivo Brain Microdialysis}

Surgery and in vivo brain microdialysis experiments were carried out as we have previously described (for example, $\mathrm{Xi}$ et al, 2003, 2010). Briefly, rats were anesthetized with sodium pentobarbital, and in vivo brain microdialysis guide cannulae were surgically implanted into the NAc at coordinates $\mathrm{AP}+1.6, \mathrm{ML} 2.0, \mathrm{DV}-4.0$, with surgical approach angle of $6^{\circ}$ from vertical. In vivo microdialysis experiments were started when animals had recovered from surgery for at least 5-7 days.

Microdialysis procedure. Microdialysis probes, as described previously (Xi et al, 2003, 2010), were inserted into the NAc through the guide cannulae at least $12 \mathrm{~h}$ before onset of experimentation to minimize effects of damageinduced neurochemical release during the experiment. Microdialysis samples were collected every $20 \mathrm{~min}$ into $10 \mu \mathrm{l}$ of $0.5 \mathrm{M}$ perchloric acid to prevent degradation of the collected chemicals. After $1 \mathrm{~h}$ of baseline sample collection, $31,345$ (10 and $20 \mathrm{mg} / \mathrm{kg})$, cocaine (10 mg/kg), methadone (5 and $8 \mathrm{mg} / \mathrm{kg}$ ), heroin $(0.25,0.5$ and $1.0 \mathrm{mg} / \mathrm{kg})$, or vehicle was administered systemically. After collection, all samples were frozen at $-80^{\circ} \mathrm{C}$ until analyzed.

Quantification of DA. Microdialysate DA was measured using high-performance liquid chromatography coupled with electrochemical detection, as we have described previously (Xi et al, 2003). The area under the curve Auc of the peak for DA was measured using the EZChrom Elite chromatography data analysis system (ESA Biosciences, Chelmsford, MA). The values of DA were quantified with an external standard curve (1-1000 pM).

\section{Intravenous Self-Administration}

Cocaine self-administration. Intravenous catheterization surgery and cocaine self-administration procedures were carried out as we have previously described (Xi et al, 2005). Briefly, i.v. catheterization was performed under sodium pentobarbital anesthesia with aseptic surgical technique. After 7 days of recovery from surgery, animals were placed into standard operant chambers (Med Associates, Saint Albans, VT) for cocaine self-administration $(0.5 \mathrm{mg} / \mathrm{kg}$ per infusion) under FR2 reinforcement. After stable cocaine-maintained responding was achieved ( $<10 \%$ variability in mean interresponse interval and $<10 \%$ variability in mean active lever presses for at least 3 consecutive days), each rat randomly received one of three doses of either $31,345(3,10$ or $20 \mathrm{mg} / \mathrm{kg}$, i.p.) or vehicle $(0.5 \mathrm{ml}, 25 \% 2$-hydroxypropyl- $\beta$-cyclodextrin, i.p.) $30 \mathrm{~min}$ before the test session. Animals then received an additional 5-7 days of self-administration of cocaine alone until the baseline response rate was reestablished before testing the next dose of 31,345 . The order of testing for the various doses of drug or vehicle was counterbalanced.

31,345 self-administration. After stable cocaine self-administration was established, one group of animals $(n=8)$ was switched to $31,345(0.5 \mathrm{mg} / \mathrm{kg}$ per infusion) to determine whether the latter would sustain self-administration. Selfadministration procedures were identical to those for cocaine. Self-administration testing continued daily for 7 consecutive days. The same animals were then switched to vehicle (saline, $0.1 \mathrm{ml}$ per infusion) for self-administration testing.

31,345-triggered reinstatement. After stable cocaine selfadministration was established, animals were exposed to extinction conditions, during which cocaine was replaced by saline, and the cocaine-associated cue light and tone were turned off. Daily 3-h extinction sessions for each rat continued until that rat lever pressed $<10$ times per 3 -h session for at least 3 consecutive days. After meeting these extinction criteria, animals randomly received vehicle or one dose of $31,345(1,3$, or $10 \mathrm{mg} / \mathrm{kg}$, i.p.) immediately before the initiation of reinstatement testing. During reinstatement testing, conditions were identical to those in extinction sessions. Drug-induced active lever-pressing responses (reinstatement) were recorded, but did not lead to either cocaine infusions or presentation of the conditioned cues. Reinstatement test sessions lasted for $3 \mathrm{~h}$.

Heroin self-administration. The procedure for heroin selfadministration was identical to that for cocaine selfadministration, except that the initial training dose of heroin was $0.1 \mathrm{mg} / \mathrm{kg}$ per infusion, subsequently reduced to $0.05 \mathrm{mg} / \mathrm{kg}$ per infusion for the actual experiments. After stable self-administration was established, each rat randomly received one of three doses of methadone $(0,5$, $8 \mathrm{mgkg}$, i.p.) $2 \mathrm{~h}$ before the test session. Animals then received an additional 5-7 days of self-administration of heroin alone until the baseline response rate was reestablished before testing the next dose of methadone. The effects of methadone on heroin self-administration were observed.

Methadone self-administration. After stable heroin selfadministration was established, one group of animals $(n=11)$ was switched to methadone $(0.1 \mathrm{mg} / \mathrm{kg}$ per infusion) to determine whether the latter would sustain self-administration. Self-administration procedures were identical to those for heroin. Self-administration testing continued daily for 7 consecutive days. The same animals were then switched to vehicle (saline, $0.1 \mathrm{ml}$ per infusion) for self-administration testing.

Methadone-triggered reinstatement. After stable heroin self-administration was established, animals were exposed to extinction conditions, during which heroin was replaced by saline, and the heroin-associated cue light and tone were turned off. Daily 3-h extinction sessions for each rat continued until that rat lever pressed $<10$ times per 3-h session for at least 3 consecutive days. After meeting these extinction criteria, animals randomly received vehicle or one dose of methadone $(1,2,3$ or $5 \mathrm{mg} / \mathrm{kg}$, i.p., s.c.) or heroin $(0.25 \mathrm{mg} / \mathrm{kg}$, s.c.) immediately before the initiation of reinstatement testing. During reinstatement testing, conditions were identical to those in extinction sessions. Druginduced active lever-pressing responses (reinstatement) were recorded, but did not lead to either heroin infusions or presentation of the conditioned cues. Reinstatement test sessions lasted for $3 \mathrm{~h}$.

\section{Locomotor Activity Measurement}

The effects of methadone on locomotion were assessed in heroin self-administration rats. Before methadone 
administration, each animal was placed in a locomotor detection chamber (Accuscan, Columbus, $\mathrm{OH}$ ) for habituation ( $3 \mathrm{~h}$ per day for 3 days). On test days, animals randomly received one of three different doses of methadone $(0,5$, or $8 \mathrm{mg} / \mathrm{kg}$, i.p.), and were then placed into the locomotor detection monitors for $5 \mathrm{~h}$. After each test, animals received an additional 3 days of heroin self-administration. The order of testing for various doses of methadone was counterbalanced.

\section{Histology}

After BSR or in vivo microdialysis experiments, rats were given an overdose of pentobarbital ( $>100 \mathrm{mg} / \mathrm{kg}$, i.p.) and transcardially perfused with $0.9 \%$ saline followed by $10 \%$ formalin. Brains were removed and placed in $10 \%$ formalin for at least 1 week. Tissue was blocked around the anatomic site of the electrode tip or guide cannula, and sections ( $100 \mu \mathrm{m}$ thick) were made by vibratome through the area. The brain sections were then stained with cresyl violet. Anatomical placement was verified by visual microscopic examination.

\section{Data Analyses}

All data are presented as means $\pm S E M$. One-way or two-way analyses of variance (ANOVA) were used to analyze the effects of 31,345 or methadone on cocaine's or heroin's behavioral or neurochemical effects. Individual group comparisons were carried out using the Bonferroni $t$ statistic for pre-planned a priori comparisons.

\section{RESULTS}

\section{Effects of 31,345 on BSR and on Cocaine-Enhanced BSR}

Figure $2 \mathrm{a}$ shows that systemic administration of 31,345 $(10 \mathrm{mg} / \mathrm{kg}$, i. p.) produced a sustained enhancement of BSR, an effect that lasted for $\sim 6 \mathrm{~h}$ when compared with pre-drug baseline and for at least $24 \mathrm{~h}$ when compared with the vehicle treatment group. Two-way ANOVA for repeated measurements over time revealed a statistically significant treatment main effect $\left(F_{1,11}=35.23, p<0.001\right)$, time main effect $\left(F_{1,9}=5.07, p<0.001\right)$, and treatment $\times$ time interaction $\left(F_{9,99}=2.31, p<0.05\right)$. Figure $2 \mathrm{~b}$ shows that 31,345-induced enhancement of BSR was dose dependent $\left(F_{3,12}=13.56, p<0.001\right)$. Figure $2 \mathrm{c}$ shows that pretreatment with 31,345 produced an augmentation of cocaine's enhancement of BSR in a dose-dependent manner $\left(F_{3,24}=5.18\right.$, $p<0.01)$. Individual group comparison results are directly marked on each individual figure panel.

\section{Effects of 31,345 on Basal and Cocaine-Enhanced NAc DA}

Figure 3a shows that $31,345(10,20 \mathrm{mg} / \mathrm{kg}$, i.p. $)$ produced a dose-dependent long-term $(>12 \mathrm{~h})$ increase in NAc DA, with a 20-60 min latency of onset. In contrast, acute cocaine $(10 \mathrm{mg} / \mathrm{kg}$, i.p.) produced a rapid and short-term increase in NAc DA. Two-way ANOVA for repeated measurements over time indicated a statistically significant treatment main effect $\left(F_{2,14}=22.50, p<0.001\right)$. Individual group comparisons
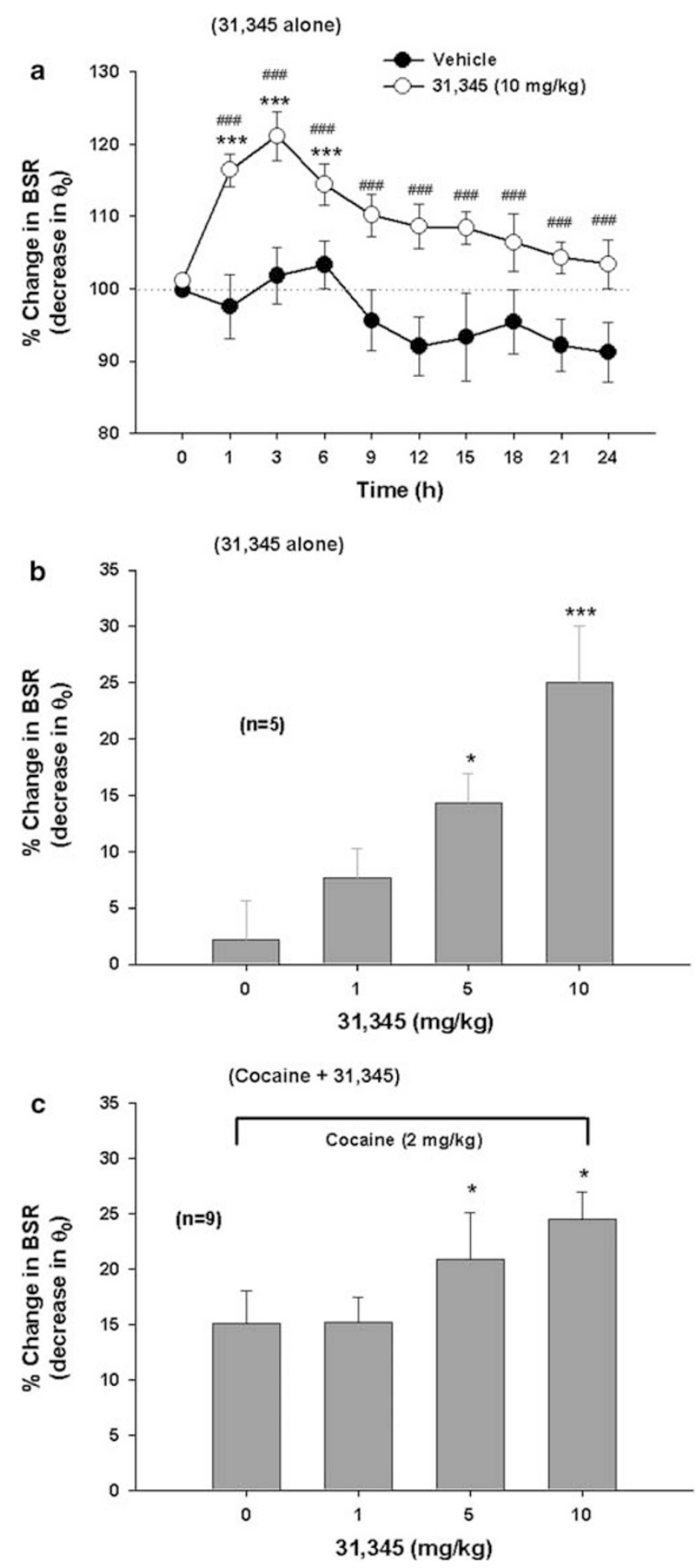

Figure 2 Effects of 31,345 on electrical brain-stimulation reward (BSR) and on cocaine-enhanced BSR. (a) A single injection of $31,345(10 \mathrm{mg} / \mathrm{kg}$, i.p.) produced a sustained enhancement of BSR, as assessed by decreased stimulation threshold $\left(\theta_{0}\right)$. (b) The dose-orderly enhancing effect of 3I,345 alone (I, 5, or $10 \mathrm{mg} / \mathrm{kg}$, i.p.) on BSR. (c) The effects on BSR of combining 31,345 ( 1,5 , or $10 \mathrm{mg} / \mathrm{kg}$, i.p.) with cocaine $\left(2 \mathrm{mg} / \mathrm{kg}\right.$, i.p.). ${ }^{*} p<0.05$, **** $p<0.001$, compared with baseline before 31,345 administration ( 0 time point in a). ${ }^{\# \# \#} p<0.001$, compared with the vehicle (saline) treatment group. 

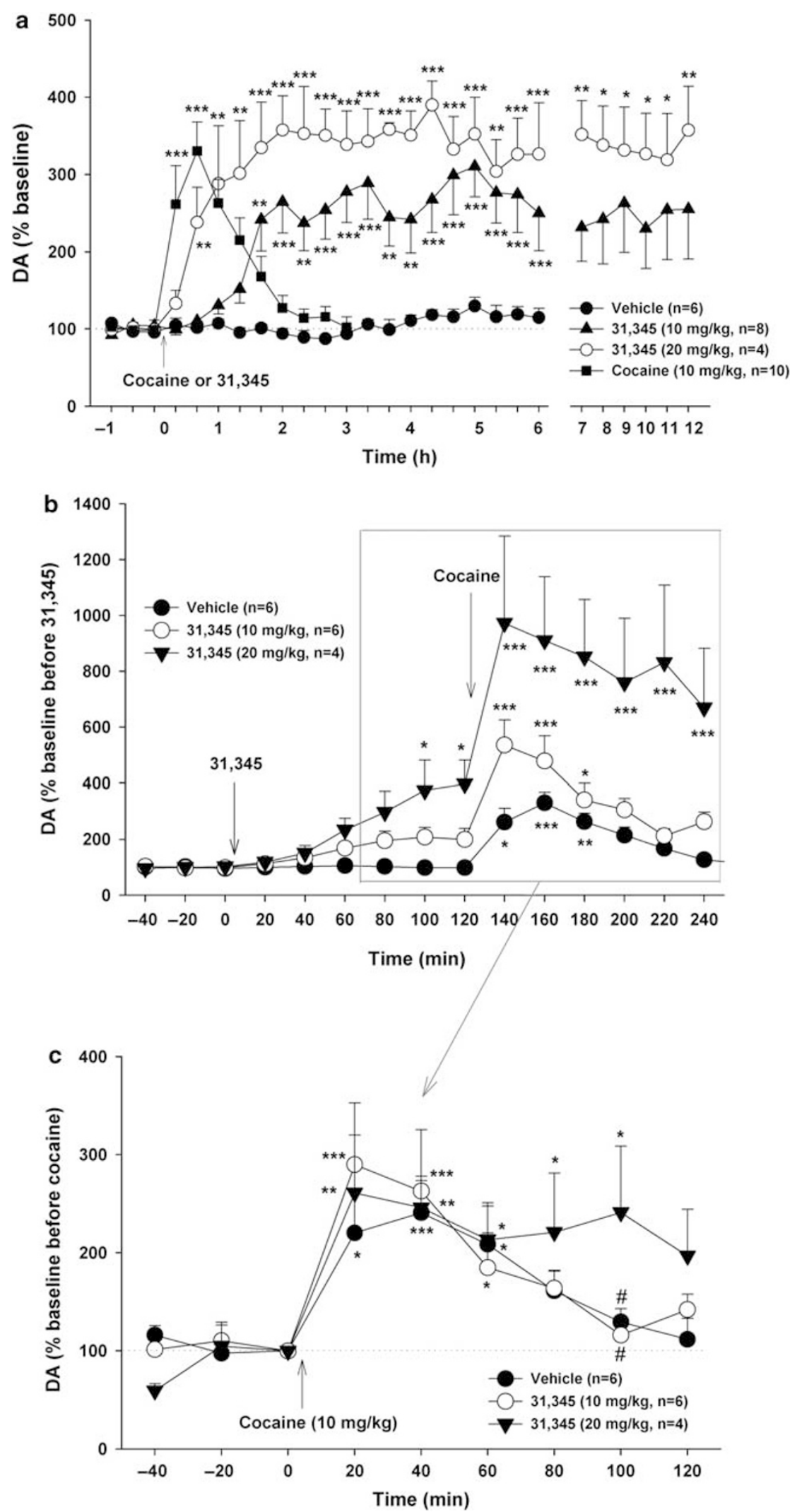

Figure 3 Effects of 31,345 and/or cocaine on extracellular NAc DA. (a) 31,345 (I0 and 20 mg/kg, i.p.) produced a dose-dependent slow-onset (20-60 min) long-acting (at least 6-12 h) increase in NAc DA, whereas cocaine $(10 \mathrm{mg} / \mathrm{kg}$, i.p.) produced a robust rapid-onset short-duration increase in NAc DA. (b) The effect of 31,345 ( 10 and $20 \mathrm{mg} / \mathrm{kg}$, i.p.) pretreatment on cocaine-enhanced extracellular NAc DA. (c) Renormalized cocaine-induced changes (percentage over new baseline immediately before cocaine administration) in NAc DA, as affected by 31,345 (I0 and $20 \mathrm{mg} / \mathrm{kg}$, i.p.) pretreatment. $* p<0.05$, $* * p<0.01$, $* * * * p<0.00$ I, compared with baseline before cocaine or 31,345 administration (a) or before 31,345 (b) or cocaine (c) administration in each treatment group. ${ }^{\#} p<0.05$, compared with $20 \mathrm{mg} / \mathrm{kg} 31,345100 \mathrm{~min}$ post-cocaine. 

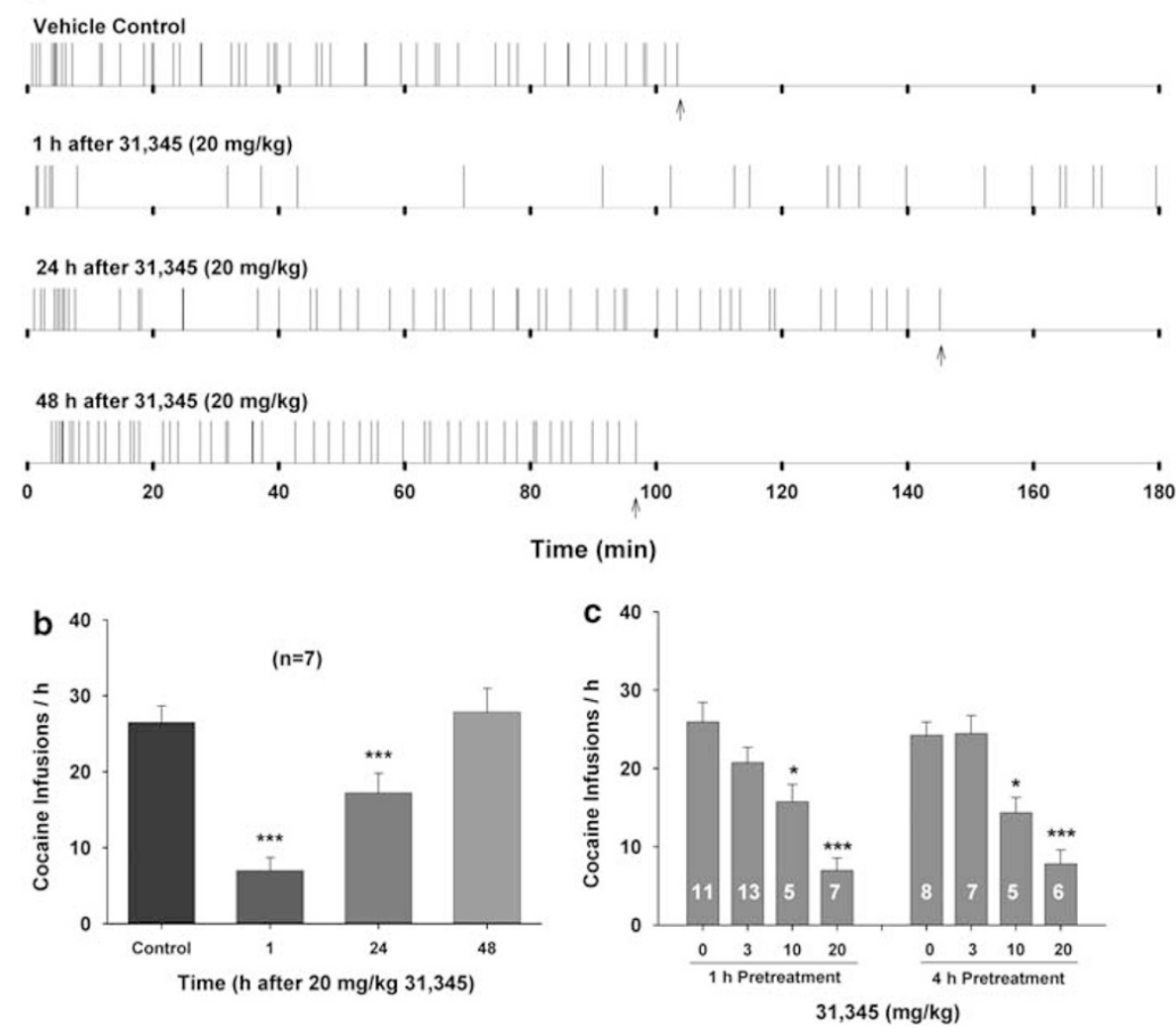

Figure 4 Effects of 31,345 pretreatment on intravenous cocaine self-administration behavior in rats. (a) Representative records of cocaine selfadministration illustrating a reduction in cocaine self-administration rate and an increase in interinfusion interval after $20 \mathrm{mg} / \mathrm{kg} 31,345$ pretreatment. Each vertical line represents one cocaine infusion. Arrows indicate end of session. (b) Mean cocaine self-administration (infusion) rates over time after 31,345 pretreatment. (c) The dose-orderly effect of 31,345 on cocaine self-administration, when 31,345 was given either I h or 4h before the beginning of cocaine self-administration testing. $* 0<0.05, * * * * 0.001$, compared with vehicle pretreatment group. Numbers within bars indicate group size.

indicated that 31,345 -induced increases in DA were statistically significant after $10 \mathrm{mg} / \mathrm{kg}$ cocaine or $10 \mathrm{mg} / \mathrm{kg}$ or $20 \mathrm{mg} / \mathrm{kg} 31,345$ administration, when compared with baselines in each dose group.

Figure $3 \mathrm{~b}$ and $\mathrm{c}$ shows that pretreatment with 31,345 (10 or $20 \mathrm{mg} / \mathrm{kg}$, i.p., $2 \mathrm{~h}$ before cocaine) produced minimal overall effect on cocaine's enhancement of NAc DA, as compared with vehicle pretreatment. Renormalization of cocaine-enhanced DA data illustrated in Figure $3 \mathrm{~b}$ based on baselines immediately before cocaine administration indicated that, overall, 31,345 pretreatment had relatively minimal effect on cocaine's enhancing action on NAc extracellular DA (Figure 3c). Two-way ANOVA for repeated measurements for the data shown in Figure $3 \mathrm{c}$ revealed a statistically significant effect of time $\left(F_{8,104}=17.00\right.$, $p<0.001)$, but not of treatment $\left(F_{2,13}=0.16, p>0.05\right)$ nor of treatment $\times$ time interaction $\left(F_{16,104}=1.03, p=0.44\right)$. Further analysis of the data set for the 80-, 100-, and 120min time points (Figure $3 \mathrm{c}$ ) revealed that the highest dose of $31,345(20 \mathrm{mg} / \mathrm{kg}$, i.p.) produced a significant prolongation of cocaine's enhancement of NAc DA $\left(F_{4,26}=2.73, p=0.05\right)$.

\section{Pretreatment with 31,345 Decreases Cocaine Self-Administration}

Figure 4a shows representative records of cocaine selfadministration under FR2 reinforcement, illustrating that
$20 \mathrm{mg} / \mathrm{kg}$ of 31,345 significantly decreased cocaine selfadministration rate and increased cocaine interinfusion intervals. The reduction in cocaine infusion rate was observed $1 \mathrm{~h}$ after 31,345 administration and lasted for $\sim 24 \mathrm{~h}$. Figure $4 \mathrm{~b}$ shows the mean time course of 31,345 induced reduction in cocaine self-administration. One-way ANOVA indicated a significant reduction in cocaine selfadministration after 31,345 administration $\left(F_{3,18}=74.46\right.$, $p<0.001)$. Figure $4 \mathrm{c}$ shows the dose effects of 31,345 on cocaine self-administration, indicating that 31,345 dose-dependently decreased cocaine self-administration rates when given either $1 \mathrm{~h}\left(F_{3,32}=11.92, p<0.001\right)$ or $4 \mathrm{~h}$ $\left(F_{3,22}=17.18, p<0.001\right)$ before cocaine self-administration testing. Importantly, cocaine self-administration showed no extinction-like behavioral pattern after 31,345 administration. 31,345 did not significantly alter inactive lever presses (data not shown).

\section{1,345 Self-Administration and 31,345-Triggered Reinstatement of Drug Seeking}

To determine abuse liability of 31,345 , we observed whether 31,345 was capable of maintaining self-administration behavior in cocaine self-administration rats. Figure 5a and b shows that 31,345 , at $0.5 \mathrm{mg} / \mathrm{kg}$ per infusion, maintained a low rate of self-administration without an obvious extinction pattern over 7 consecutive days. In contrast, when the 
a Cocaine SA - Day 0

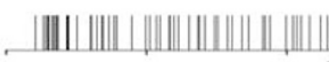

\section{$\Lambda$}

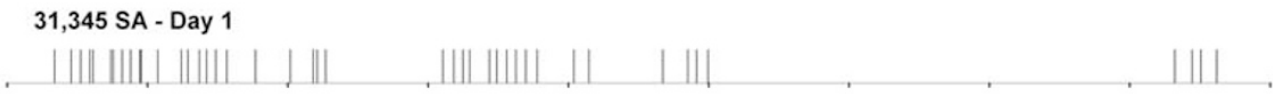

31,345 SA - Day 3
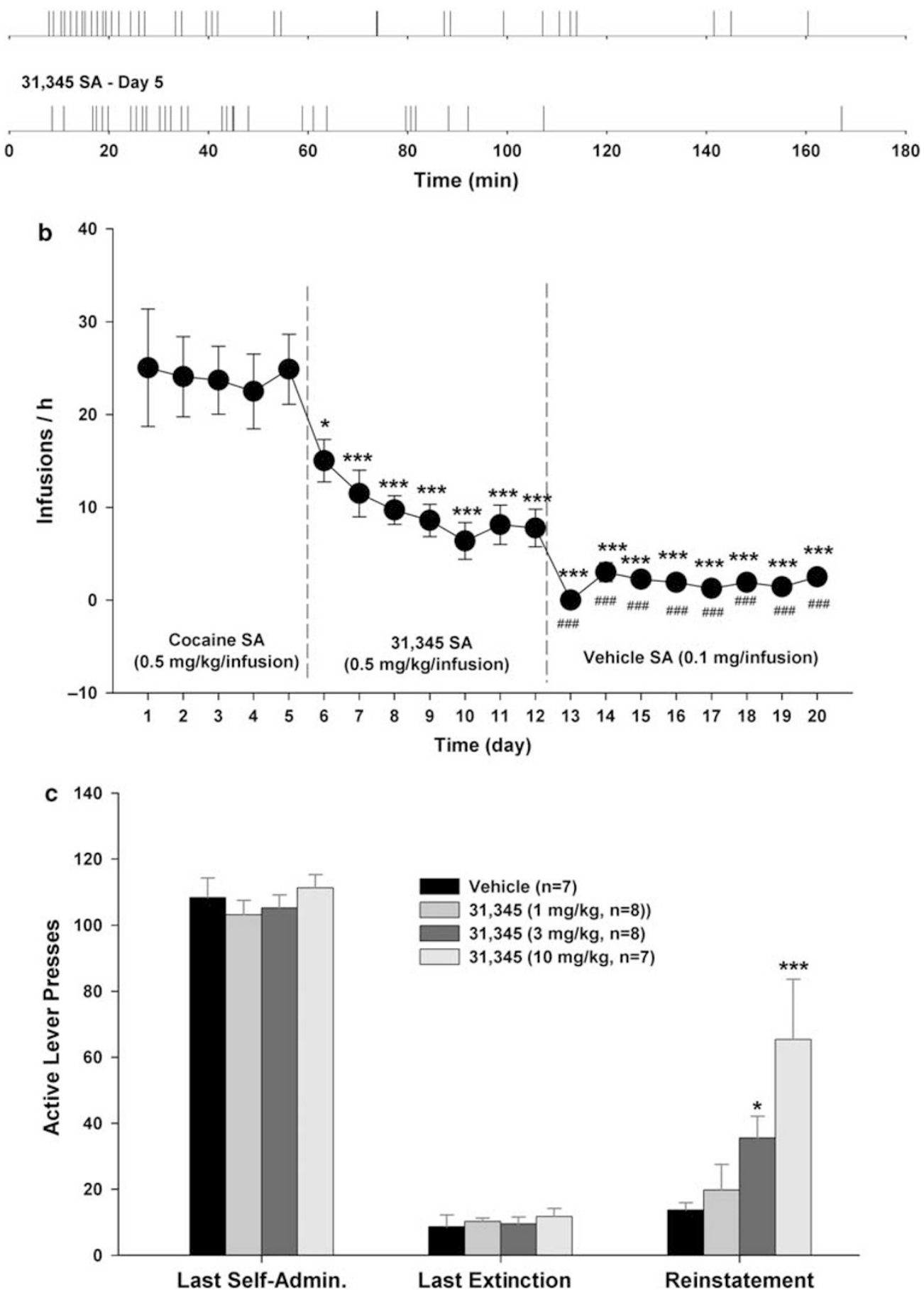

Figure 5 Compound 31,345 self-administration substitution tests and 31,345-triggered reinstatement of drug-seeking behavior. (a) Representative records of cocaine $(0.5 \mathrm{mg} / \mathrm{kg}$ per infusion) or $31,345(0.5 \mathrm{mg} / \mathrm{kg}$ per infusion) self-administration over a span of seven consecutive daily replacement tests. Arrows indicate end of session. (b) Mean self-administration rate during cocaine, 31,345, or vehicle self-administration testing. (c) 31,345 ( I, 3 or I 0 mg/ $/ \mathrm{kg}$, i.p.)-induced reinstatement of drug-seeking behavior. $* p<0.05$, $* * * * 0<001$, compared with the last day of cocaine self-administration in $b$ or vehicle $(0 \mathrm{mg} / \mathrm{kg} 31,345)$ in $c .{ }^{\# \#} p<0.001$, compared with the last day of 31,345 self-administration testing. 
same rats were switched to vehicle, self-administration behavior was not maintained (Figure 5b). One-way ANOVA for repeated measures revealed a statistically significant time main effect of time (Figure 5b: $F_{7,49}=6.40, p<0.001$ ), and individual group comparisons indicated a significant reduction in self-administration after substitution of 31,345 , as compared with the last day of cocaine self-administration. Importantly, infusion rates during 31,345 substitution were significantly higher than those for vehicle (Figure $5 b$ ). There were no significant alterations in inactive lever presses (data not shown). Figure $5 c$ shows that 31,345 (1, 3, or $10 \mathrm{mg} / \mathrm{kg}$, i.p.) reinstated drug-seeking behavior in a dose-orderly fashion in rats extinguished from previous cocaine self-administration $\left(F_{5,40}=4.63, p<0.01\right)$.

\section{Effects of Methadone on BSR and on Heroin-Enhanced BSR}

Figure 6a shows that methadone produced a significant enhancement of BSR $\left(F_{4,25}=5.06 ; p<0.01\right)$, with peak enhancement at $3 \mathrm{mg} / \mathrm{kg}(t=4.18, p<0.01)$, as compared with vehicle. Figure $6 \mathrm{~b}$ shows that heroin, at a dose of $0.2 \mathrm{mg} / \mathrm{kg}$, produced a significant enhancement $(\sim 18 \%)$ of BSR, as compared with vehicle. Pretreatment with methadone produced a dose-dependent inhibition of heroininduced BSR enhancement (one-way ANOVA: $F_{4,23}=6.09$, $p<0.01$ ). Individual group comparisons revealed a significant inhibition of heroin-enhanced BSR after $5 \mathrm{mg} / \mathrm{kg}$ $(t=3.01, \quad p<0.05)$ or $8 \mathrm{mg} / \mathrm{kg}$ methadone $(t=3.71$, $p<0.05)$ administration. Figure $6 c$ shows the effects of methadone pretreatment on different doses of heroinenhanced BSR, demonstrating that $5 \mathrm{mg} / \mathrm{kg}$ methadone pretreatment significantly attenuated BSR-enhancing effects produced by $0.2 \mathrm{mg} / \mathrm{kg} \quad(t=2.43, \quad p<0.05), \quad 0.3 \mathrm{mg} / \mathrm{kg}$ $(t=2.51, p<0.05)$, but not by $0.1 \mathrm{mg} / \mathrm{kg}$, of heroin.

\section{Effects of Methadone on Basal and Heroin-Enhanced NAc DA}

Figure 7 a shows that methadone alone $(5$ and $8 \mathrm{mg} / \mathrm{kg}$, i.p.) significantly increased NAc extracellular DA with a dosedependent increase in the duration, but not amplitude. Two-way ANOVA for repeated measurements revealed a statistically significant treatment main effect $\left(F_{2,16}=12.33\right.$, $p<0.001)$, time main effect $\left(F_{14,310}=12.61, p<0.001\right)$, and treatment $\times$ time interaction $\left(F_{28,310}=4.22, \quad p<0.001\right)$. Figure $7 \mathrm{~b}$ shows that pretreatment with methadone significantly attenuated heroin-enhanced NAc DA. Renormalization of the changes in NAc DA produced by the combined actions of methadone plus heroin over baselines immediately before heroin administration (Figure 7c) revealed a significant blockade by methadone of heroinenhanced NAc DA. Two-way ANOVA for repeated measurements over time of the data shown in Figure $7 \mathrm{c}$ indicated a statistically significant treatment main effect $\left(F_{2,21}=9.28, p<0.01\right)$, time main effect $\left(F_{14,294}=11.08\right.$, $p<0.001)$, and treatment $\times$ time interaction $\left(F_{28,294}=11.08\right.$, $p<0.001)$. Individual group comparisons indicated that methadone pretreatment significantly inhibited heroininduced NAc DA augmentation after $5 \mathrm{mg} / \mathrm{kg}(t=2.95$, $p<0.05)$ or $8 \mathrm{mg} / \mathrm{kg}(t=4.08, p<0.01)$ methadone pretreatment. Figure $7 \mathrm{~d}$ shows that pretreatment with methadone
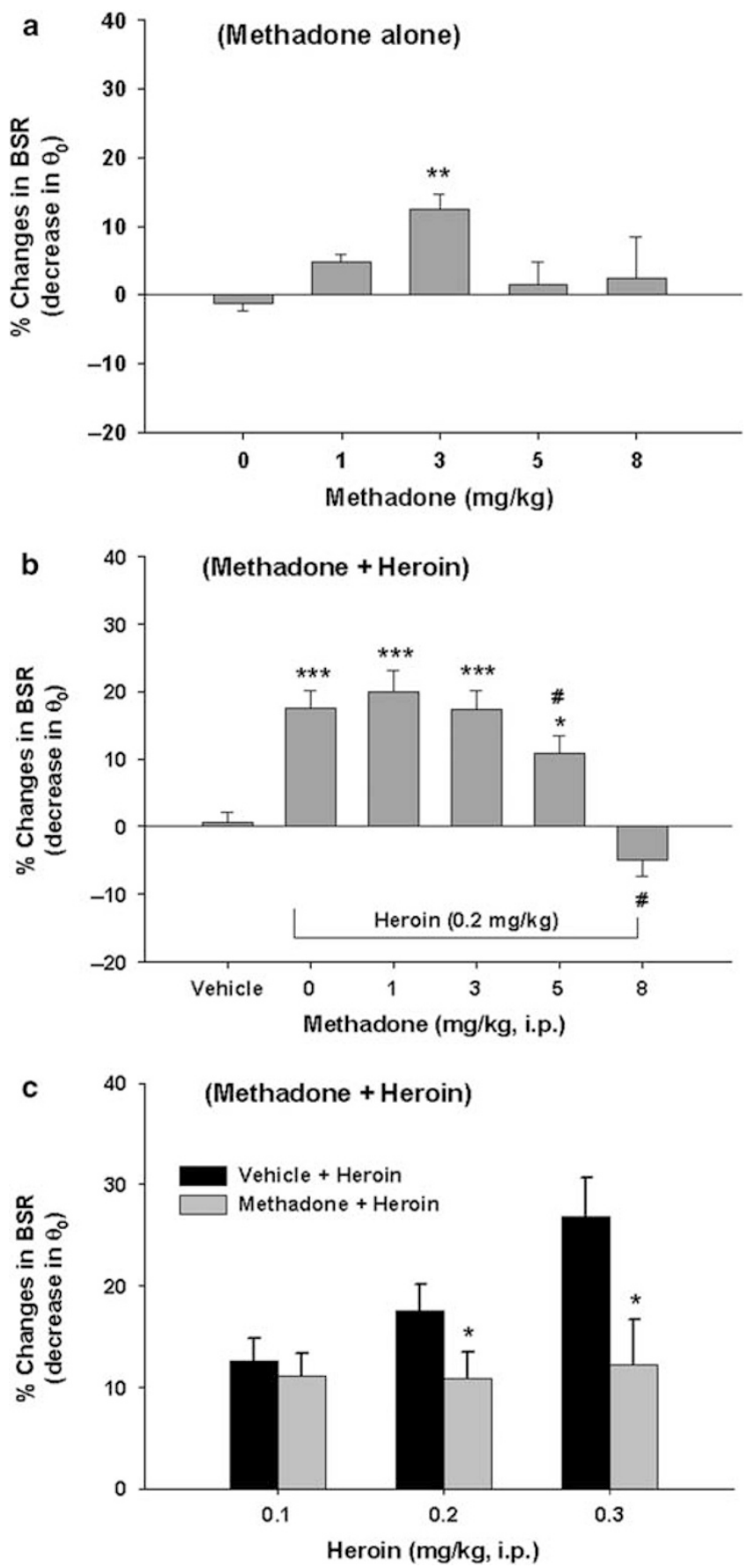

Figure 6 Effects of methadone alone (I, 3, 5 or $8 \mathrm{mg} / \mathrm{kg}$, i.p.) on electrical brain-stimulation reward (BSR), and of methadone pretreatment on heroin-enhanced BSR. (a) Methadone at $3 \mathrm{mg} / \mathrm{kg}$ (but not at the other doses tested) significantly enhanced BSR, as assessed by a decrease in the stimulation threshold $\left(\theta_{0}\right)$. (b) Methadone at 5 or $8 \mathrm{mg} / \mathrm{kg}$ dosedependently attenuated heroin-enhanced BSR. (c) Methadone at $5 \mathrm{mg} / \mathrm{kg}$ blocked heroin-induced dose-dependent enhancement of BSR. $* p<0.05$, *** $<<0.0$ I, **** $p<0.00 \mathrm{I}$, compared with $0 \mathrm{mg} / \mathrm{kg}$ methadone in a or vehicle in $b$ or vehicle + heroin in $c ;{ }^{\#} p<0.05$, compared with the $0 \mathrm{mg} / \mathrm{kg}$ methadone (that is, $0.2 \mathrm{mg} / \mathrm{kg}$ heroin alone) treatment group in $\mathrm{b}$.

( $5 \mathrm{mg} / \mathrm{kg}, 2 \mathrm{~h}$ before heroin) significantly shifted heroin's dose-response effect on extracellular DA downward and to the right. Two-way ANOVA for repeated measures over heroin dose (Figure $7 \mathrm{~d}$ ) revealed a statistically significant treatment (vehicle $v s$ methadone) main effect $\left(F_{1,18}=34.25\right.$, 

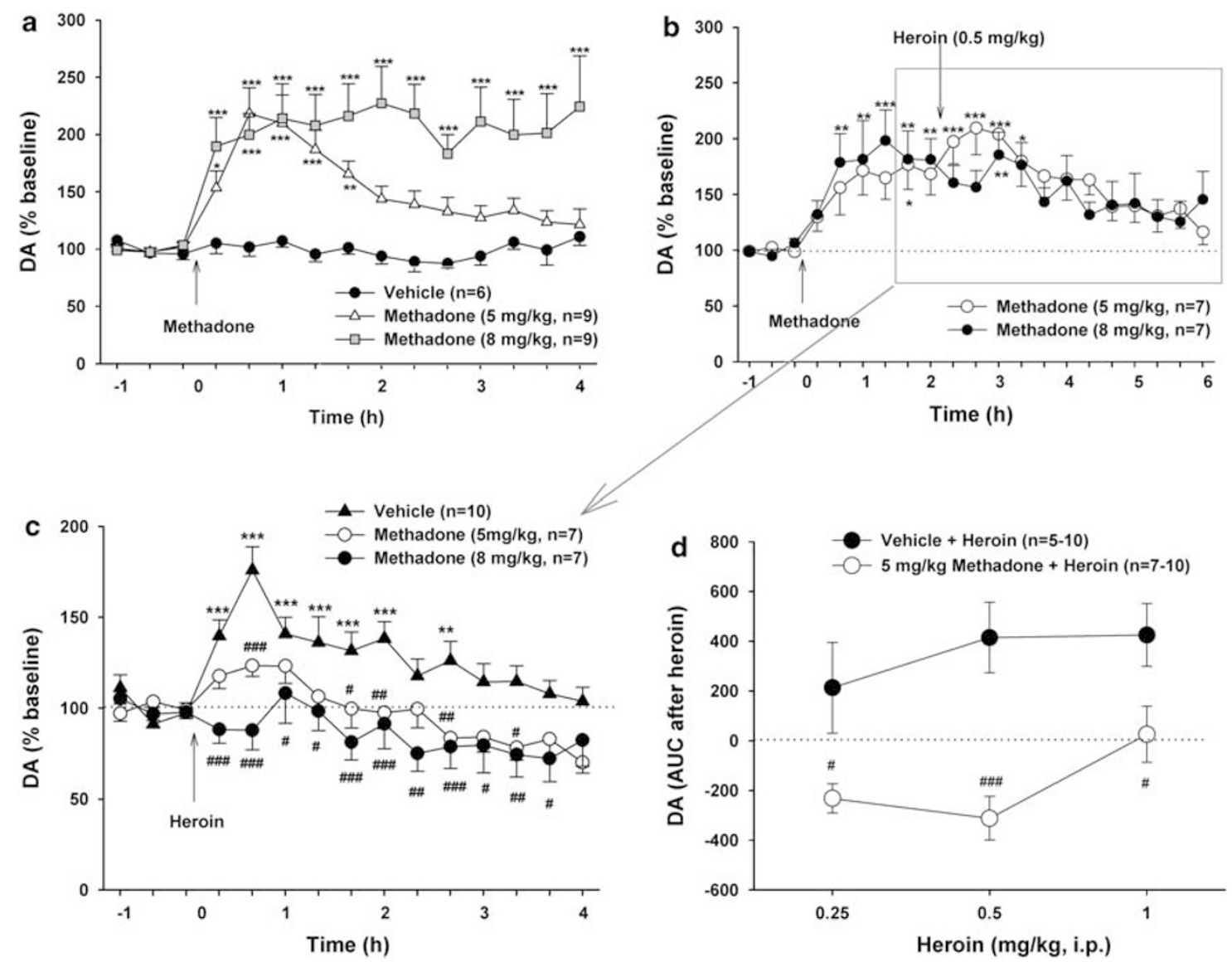

Figure 7 Effects of methadone and/or heroin on extracellular NAc DA. (a) The dose effects of methadone (0, 5, or 8 mg/kg, i.p.) on NAc DA. (b) Percent changes (\%) in NAc DA after methadone and subsequent heroin administration (over premethadone baseline). (c) Renormalized percent changes (\%) in NAc DA after heroin administration (over the new preheroin baseline). (d) Methadone at $5 \mathrm{mg} / \mathrm{kg}$ shifted heroin dose effects on extracellular DA downward and to the right. ${ }^{*} p<0.05$, ${ }^{*} p<<0.01$, **** $p<0.001$, compared with baseline before methadone or heroin administration. ${ }^{\#} p<0.05,{ }^{\# \#} p<0.01$, $\# \#$ \# $<0.001$, compared with the vehicle + heroin treatment group.

$p<0.001$ ), but not a statistically significant heroin dose main effect $\left(F_{2,18}=2.79, p=0.088\right)$. Individual group comparisons revealed a significant reduction in heroinenhanced extracellular DA at each dose of heroin after methadone pretreatment (Figure $7 \mathrm{~d}$ ).

\section{Effects of Methadone on Heroin Self-Administration}

Figure 8 shows that pretreatment with methadone, at $5 \mathrm{mg} / \mathrm{kg}$, produced a significant reduction in heroin selfadministration rate and an increase in heroin interinfusion intervals (Figure 8a). When the dose was increased to $8 \mathrm{mg} / \mathrm{kg}$, methadone produced complete cessation of heroin self-administration in five of eight animals tested (Figure $8 \mathrm{a}$ and $b$ ), with the other three animals displaying a typical extinction pattern of heroin self-administration, that is, an initial robust increase of, followed by cessation of, drugseeking behavior (pattern not shown). Figure $8 \mathrm{~b}$ shows the time courses of heroin self-administration after different doses of methadone pretreatment. Figure $8 \mathrm{c}$ shows the mean numbers of infusions or inactive lever presses after methadone administration. One-way ANOVA revealed a statistically significant reduction in the mean numbers of heroin infusions (Figure $8 \mathrm{c}$, left panel: $F_{2,14}=39.53$, $p<0.001)$ after $5 \mathrm{mg} / \mathrm{kg}(t=2.96, p<0.05)$ or $8 \mathrm{mg} / \mathrm{kg}$ $(t=8.74, p<0.001)$ methadone pretreatment. In contrast, methadone did not significantly alter the number of inactive lever presses (Figure 8c, right panel), suggesting a selective inhibition of heroin-seeking behavior. To further determine whether such inhibition in heroin self-administration is due to a reduction in locomotor ability after methadone administration, we further observed the effects of methadone on locomotor activity in heroin self-administration rats. We found that the same doses of methadone (5 and $8 \mathrm{mg} / \mathrm{kg}$ ) did not produce significant inhibition of locomotor activity within $5 \mathrm{~h}$ after methadone pretreatment (data not shown).

\section{Methadone Self-Administration and Methadone-Triggered Reinstatement of Drug Seeking}

Figure 9a shows representative methadone self-administration records in rats previously trained for heroin selfadministration. Methadone, at the same dose $(0.05 \mathrm{mg} / \mathrm{kg})$ as heroin, failed to maintain self-administration (data not shown). However, when the dose was increased to $0.1 \mathrm{mg} / \mathrm{kg}$ per infusion, methadone maintained a high rate of selfadministration initially (substitution days 1 and 2), which then progressively decreased over time (daily sessions) with an extinction-like pattern (Figure 9a and b). When the same rats were switched to vehicle, self-administration behavior was not maintained (Figure 9b). Figure 9c shows that 


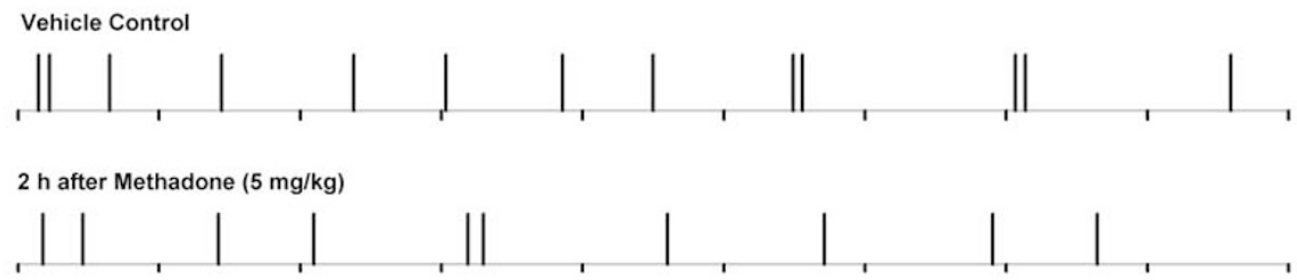

$2 \mathrm{~h}$ after Methadone $(8 \mathrm{mg} / \mathrm{kg})$

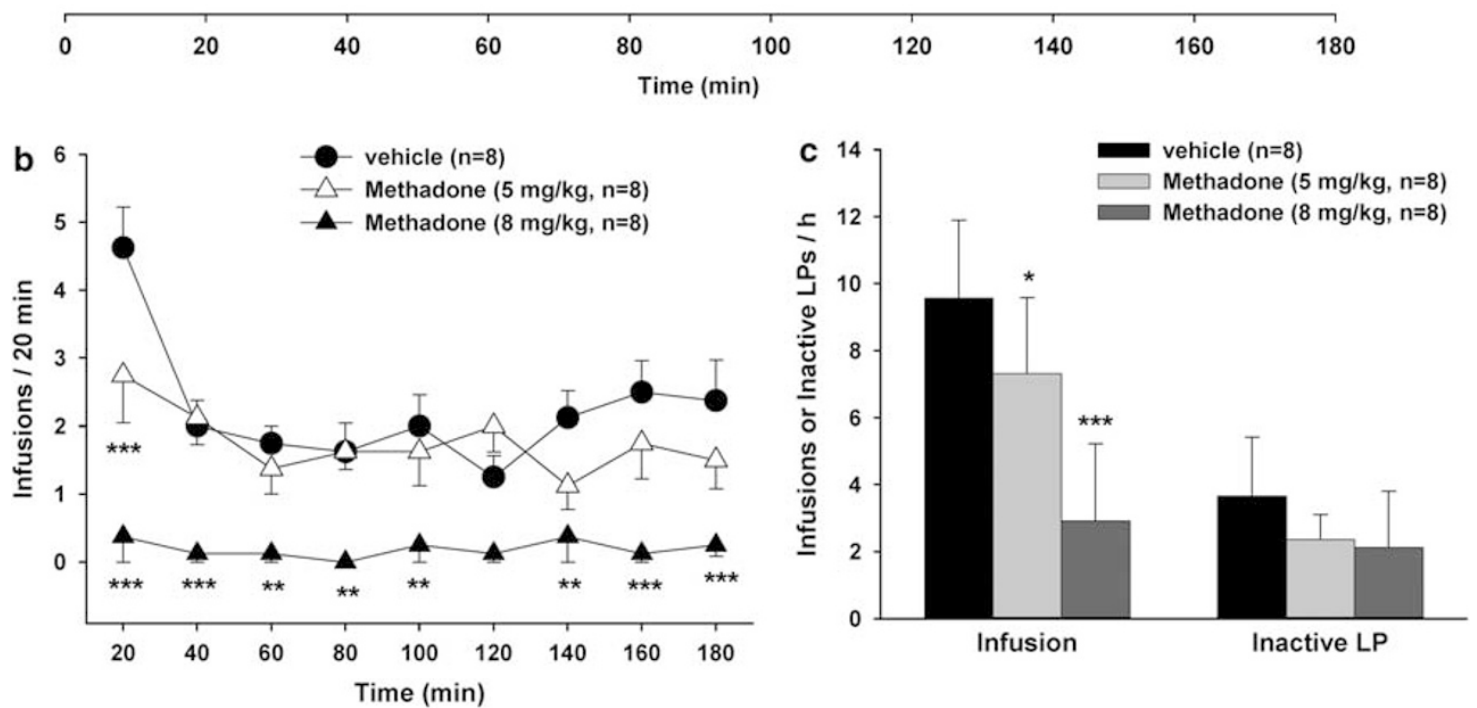

Figure 8 Effects of methadone pretreatment on heroin self-administration behavior in rats. (a) Representative records of heroin self-administration after vehicle or methadone pretreatment. (b) Mean heroin self-administration rates over time. (c) The total numbers of infusions or inactive lever presses during $3 \mathrm{~h}$ of heroin self-administration. ${ }^{*} p<0.05$, ${ }^{*} \mathrm{w} p<0.0 \mathrm{l}$, **** $p<0.00 \mathrm{l}$, compared with vehicle treatment group.

methadone $(1,2,3$, or $5 \mathrm{mg} / \mathrm{kg}$, s.c.) failed to reinstate extinguished heroin-seeking behavior $\left(\mathrm{F}_{4,33}=0.74, p=\mathrm{NS}\right)$, whereas heroin $(0.25 \mathrm{mg} / \mathrm{kg}$, s.c.) robustly evoked reinstatement of extinguished heroin-seeking behavior, when compared with the vehicle control group $(t=5.76, p<0.001)$.

\section{Anatomic Verification of Microdialysis Probe Placements in the Brain}

The locations of the NAc microdialysis probes are illustrated in Figure 10. The active semipermeable membranes of the microdialysis probes were located within both the medial NAc core and shell, with a small degree of preferential location within the shell compartment. There were no obvious differences in placement across the different experimental groups of rats. Subjects with probe placements outside the NAc were excluded from the experiment.

\section{DISCUSSION}

Since the development of methadone pharmacotherapy for opiate addiction (Dole and Nyswander, 1965; Dole et al, 1966), the widespread assumption has been that methadone is a longacting opioid agonist that exerts its antiopiate effects by agonist substitution (Veilleux et al, 2010). This assumption has driven the development of slow-onset long-acting monoamine or DAT inhibitors as potential pharmacotherapies for cocaine and other psychostimulant addiction (Newman and Kulkarni, 2002; Wise and Gardner, 2004; Runyon and Carroll, 2006; Rothman et al, 2008). The present experiments showed that compound 31,345 is a slow-onset, long-acting monoamine reuptake inhibitor, produced additive effects with cocaine on BSR and NAc DA, and suppressed cocaine self-administration without a behavioral extinction pattern. These properties appear to be different from the effects of methadone on heroin's actions. Methadone pretreatment dose-dependently inhibited heroinenhanced BSR, heroin-enhanced NAc DA, and heroin selfadministration with a behavioral extinction pattern. These findings suggest that methadone's therapeutic efficacy is likely to be mediated by a simultaneous combination of opiate agonist substitution for heroin's action at the $\mu$-opiate receptor plus functional antagonism of subsequent heroin actions at the $\mu$-opiate receptor. Thus, ideal anticocaine compounds should emulate methadone's actions, that is, act as functional antagonists of cocaine or other psychostimulants, while at the same time substituting for them as transporter substrates.

\section{1,345 is a Slow-Onset Long-Acting Monoamine Transporter Inhibitor}

Recent years have seen development of many DA or monoamine transporter inhibitors (Platt et al, 2002; Howell and Wilcox, 2001; Newman and Kulkarni, 2002; Runyon 


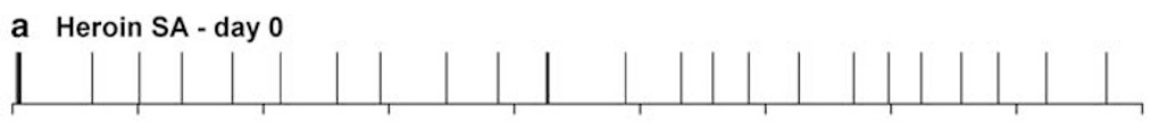

Methadone SA - day 1

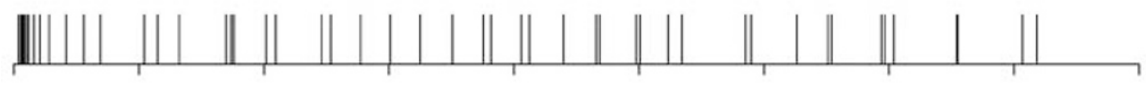

Methadone SA - day 3

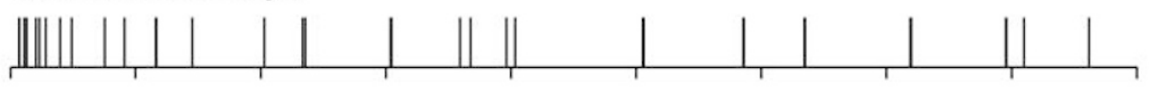

Methadone SA - day 5

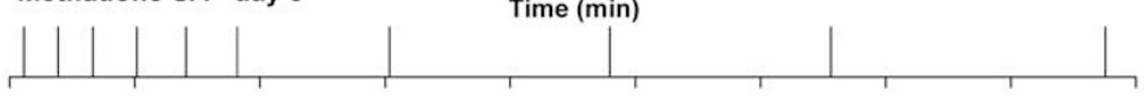

Saline Replacement - day 3
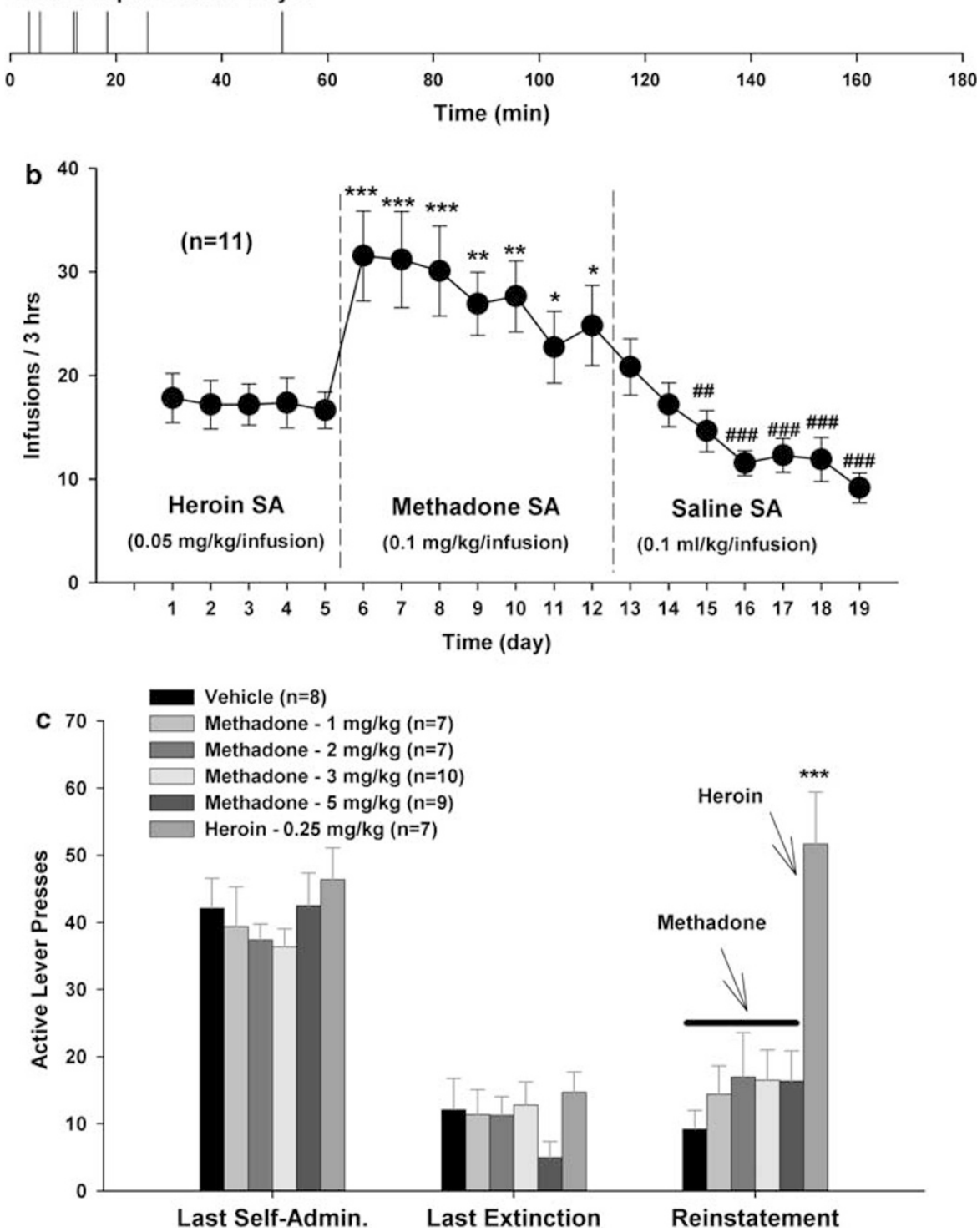

Figure 9 Methadone self-administration substitution tests and methadone-triggered reinstatement of drug-seeking behavior. (a) Representative records of heroin $(0.05 \mathrm{mg} / \mathrm{kg}$ per infusion) self-administration plus methadone $(0.1 \mathrm{mg} / \mathrm{kg}$ per infusion) self-administration (SA) over a span of seven consecutive daily replacement tests. (b) Mean self-administration rate during heroin, methadone, or vehicle self-administration testing. (c) Methadone (I, 2, 3, or $5 \mathrm{mg} / \mathrm{kg}$, s.c.) failed to reinstate heroin-seeking behavior, whereas heroin $(0.25 \mathrm{mg} / \mathrm{kg}$, s.c.) induced reinstatement of heroin-seeking behavior. $* p<0.05$, $* * * 2<0.0 \mathrm{l}$, ${ }^{*} * * * 0.00$ I, compared with the last day of heroin self-administration in b or the vehicle control group in c. ${ }^{\# \#} p<0.0$ l, ${ }^{\# \# \#} p<0.00$ I, compared with the last day of methadone self-administration testing in b. 


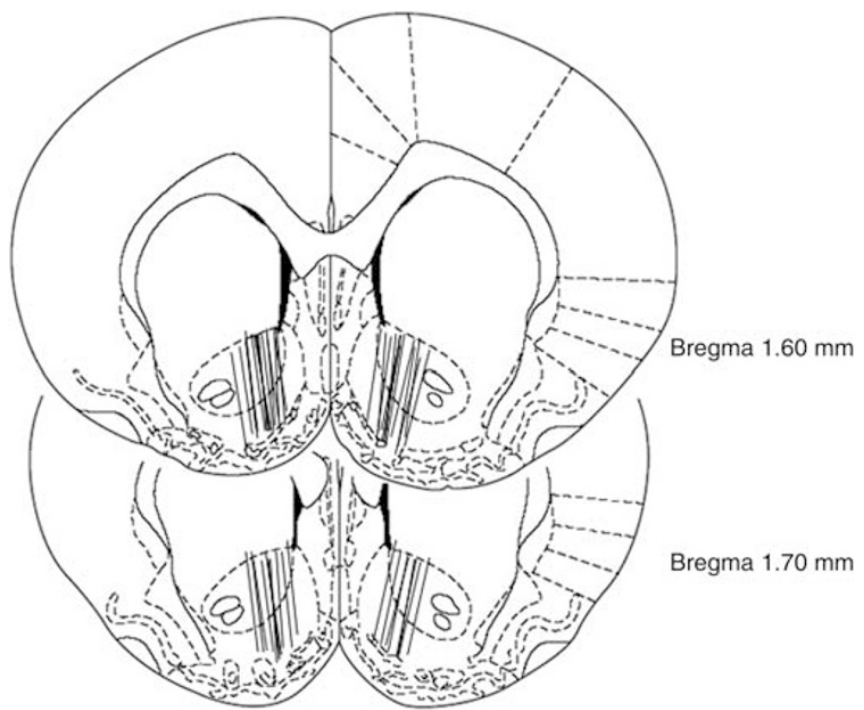

Figure 10 Coronal section depictions of the rat brain showing positions of the microdialysis probes.

and Carroll, 2006; Rothman et al, 2008), only a few of which have slow-onset, long-acting properties (Froimowitz et al, 2000, 2007; Carroll et al, 2006). Compound 31,345 is a prodrug, which is metabolized ( $N$-demethylated) to 31,346 , a potent monoamine transporter inhibitor that has relatively higher affinity for human DAT and serotonin transporters than for norepinephrine transporters $(\mathrm{Ki}=18$, 23 and $81 \mathrm{nM}$, respectively) (Welch et al, 1984). The present data demonstrate that a single injection of 31,345 produces markedly slow-onset (20-60 min) and longduration (at least $12 \mathrm{~h}$ ) BSR enhancement and augmented extracellular NAc DA. 31,345 also produced prolonged (24-48 h) suppression of i.v. cocaine self-administration. These findings confirm 31,345's slow-onset, long-acting profile.

\section{1,345 Pretreatment Inhibits Cocaine Self-Administration}

Pretreatment with 31,345 produced a dose-dependent longterm decrease in cocaine self-administration similar to that seen after a single injection of 30,640 (a slow-onset, longacting DAT inhibitor of the indanamine class) (Gardner et al, 2006) or GBR12909 decanoate (a slow-release DAT inhibitor) (Glowa et al, 1996; Howell and Wilcox, 2001). Given that drug infusion rates are located within the descending slope of the inverse U-shaped cocaine doseresponse curve for self-administration (LeSage et al, 1999; $\mathrm{Xi}$ et al, 2010), 31,345's attenuation of cocaine selfadministration suggests hedonic satiation to cocaine's rewarding effects (Gardner, 2000; $\mathrm{Xi}$ et al, 2010). This is consistent with findings that DA receptor agonists decrease, whereas antagonists increase cocaine self-administration (Koob et al, 1987; Bergman et al, 1990; Rothman and Glowa, 1995). Importantly, we did not observe extinction-like selfadministration patterns after 31,345 pretreatment, suggesting that it did not produce antagonist-like inhibition of cocaine's rewarding effects.
It is generally accepted that the addictive effects of cocaine are attributable to mesolimbic DAT inhibition (Di Chiara, 1995; Wise, 1996). We found that acute 31,345 produced sustained NAc DA elevation, whereas pretreatment with high-dose 31,345 prolonged cocaine-enhanced NAc DA. We believe that this increase in DA contributed to the observed reduction in cocaine self-administration. This augmentation may be explained by the assumption that cocaine and 31,345 have different binding sites on the DAT. On this assumption, 31,345's binding to transporters at one site may enhance cocaine's binding and/or action on the DAT. This assumption appears to be supported by recent findings that DAT conformation and function is dynamically regulated by multiple intracellular and extracellular signaling pathways (Zahniser and Sorkin, 2004; Chen and Reith, 2007). In addition, the DAT can recycle between cell surface and cytosol (Loder and Melikian, 2003; Kahlig et al, 2006), such recycling being regulated by presynaptic DA (D2, D3) receptors (Mayfield and Zahniser, 2001; Bolan et al, 2007; Zapata et al, 2007) and DAT ligands (Chi and Reith, 2003; Daws et al, 2002; Little et al, 2002). Very importantly, different DAT inhibitors produce different conformational states of the DAT, and these different conformational states differentially permit or prevent ligand binding to the DAT (Reith et al, 2001; Saunders et al, 2000; Chen et al, 2006; Loland et al, 2008). This assumption may explain the additive pharmacological effects seen after the combination of cocaine and 31,345 , speaking to satiation of mesolimbic DA hedonic substrates (present study) or antagonistic behavioral and subjective effects seen after the combination of cocaine and other DAT inhibitors (Desai et al, 2005; Ferragud et al, 2009).

\section{Methadone Pretreatment Inhibits Behavioral and Neurochemical Effects of Heroin}

Methadone pretreatment dose-dependently inhibited heroin self-administration in rats with an extinction pattern that is different from that of 31,345 on cocaine self-administration. Low-dose methadone modestly lowered heroin self-administration rate and increased interinfusion intervals, with peak effect occurring within $20 \mathrm{~min}$ after methadone administration. At higher dose, methadone completely inhibited heroin self-administration in most animals tested. This decreased heroin self-administration is unlikely to have been due to methadone-induced nonspecific motoric inhibition, because methadone neither produced motoric inhibition in rats during maintenance of heroin selfadministration (data not shown) nor altered inactive lever presses or $Y \max$ (maximal lever presses per $30 \mathrm{~s}$ ) in BSR. Thus, the simplest explanation for methadone-induced reduction in heroin self-administration is that methadone produces a dose-dependent reduction in heroin's rewarding efficacy, leading to cessation of heroin self-administration behavior after high methadone doses (Xi and Stein, 2002). This conclusion is supported by our findings that methadone dose-dependently attenuated heroin-enhanced BSR and heroin-enhanced NAc DA, blocked heroin-induced dose-dependent enhancement of BSR, and shifted heroin's dose-response effects on in BSR or extracellular DA downward and to the right. These findings are consistent with previous reports that methadone maintenance 
significantly inhibits heroin self-administration in dogs and heroin-induced reinstatement of drug-seeking behavior in rats (Jones and Prada, 1977; Leri et al, 2004), blocks striatal DA response to opioids as assessed by position emission tomography (Daglish et al, 2008), and inhibits heroin selfadministration and the heroin-induced 'high' in human addicts (Donny et al, 2002, 2005).

With respect to possible mechanisms underlying the pharmacotherapeutic effects of methadone, first, methadone binding to $\mu$-opiate receptors leads to a significant long-lasting increase in extracellular NAc DA. As opiate addicts have been shown to have significant deficits in brain DA function (Kuhar and Pilotte, 1996; Gardner, 2000; Koob et al, 2004), this increase in NAc DA produced by methadone may normalize such hypofunctional DA transmission, thereby decreasing motivation (craving) for drugseeking and drug-taking behaviors (that is, agonist substitution action). Second, methadone binding to $\mu$-opiate receptors may lead to opiate receptor internalization and cross-tolerance (Keith et al, 1998; Kramer and Simon, 1999; Patel et al, 2002), which may explain the attenuation of heroin's action on extracellular DA and brain reward functions after methadone pretreatment (that is, functional antagonist action).

\section{Potential Utility of 31,345 for Treatment of Cocaine Addiction}

It is widely believed that slow-onset long-duration DAT or monoamine transport inhibitors have less abuse potential than rapid-onset short-acting transport inhibitors such as cocaine (Volkow et al, 1995). This belief has been a major factor supporting the slow-onset, long-acting DAT inhibitor medication development strategy. However, the present findings do not appear to support this view, because 31,345 produced significant dose-dependent enhancement of BSR and NAc DA. It also dose-dependently reinstated drugseeking behavior and maintained a stable (although low) rate of self-administration behavior. These data suggest that DAT ligands with slow-onset long-acting profile still have significant abuse liability. This is congruent with similar findings with GBR12909 and other long-acting DAT inhibitors (Howell and Wilcox, 2001; Carroll et al, 2006; Gardner et al, 2006). In contrast to 31,345 , methadone replacement neither maintained stable self-administration over time in heroin self-administration rats nor reinstated extinguished drug-seeking behavior, suggesting a low abuse potential for methadone. Notwithstanding possible abuse liability, 31,345 may still have pharmacotherapeutic potential in the treatment of cocaine addiction, because (1) a single injection of 31,345 produced long-term $(>24 \mathrm{~h})$ inhibition of cocaine self-administration; (2) the selfadministration maintained by 31,345 was substantially less than that maintained by cocaine; and (3) the relatively weak reinforcing properties of 31,345 might be helpful in relieving dysphoria, craving, or abstinence symptoms.

In conclusion, the slow-onset, long-acting monoamine transporter inhibitors 31,345 (present study) and 30,640 (Gardner et al, 2006) augment cocaine's actions, whereas methadone and NRT-supplied nicotine inhibit heroin's or smoking-supplied nicotine's actions, respectively. As methadone and NRT-supplied nicotine have proven anti-addiction efficacy, we suggest that further development of anti-addiction medications using the slow-onset, longacting monoamine reuptake blockade strategy epitomized by 31,345 and 30,640 should strive to more fully emulate methadone's action on heroin's effects, that is, to inhibit, rather than augment, cocaine's actions on brain reward and NAC DA. Lacking that functional antagonism, the anticocaine medication development strategy with slowonset, long-acting DAT or monoamine transport inhibitors may fall short of full success.

\section{ACKNOWLEDGEMENTS}

This research was supported by the Intramural Research Program of the National Institute on Drug Abuse, National Institutes of Health. We thank Drs Maarten EA Reith of New York University School of Medicine and Jonathan L Katz of the Intramural Research Program, National Institute on Drug Abuse for helpful discussions and suggestions.

\section{DISCLOSURE}

The authors declare that, except for income received from their primary employers, no financial support or compensation has been received from any individual or corporate entity over the past 3 years for research or professional service, and there are no personal financial holdings that could be perceived as constituting a potential conflict of interest.

\section{REFERENCES}

Bergman J, Kamien JB, Spealman RD (1990). Antagonism of cocaine self-administration by selective dopamine $D_{1}$ and $D_{2}$ antagonists. Behav Pharmacol 1: 355-363.

Bolan EA, Kivell B, Jaligam V, Oz M, Jayanthi LD, Han Y et al (2007). $D_{2}$ receptors regulate dopamine transporter function via an extracellular signal-regulated kinases 1 and 2-dependent and phosphoinositide 3 kinase-independent mechanism. Mol Pharmacol 71: 1222-1232.

Busto U, Sellers EM (1986). Pharmacokinetic determinants of drug abuse and dependence. A conceptual perspective. Clin Pharmacokinet 11: 144-153.

Carroll FI, Howard JL, Howell LL, Fox BS, Kuhar MJ (2006). Development of the dopamine transporter selective RTI-336 as a pharmacotherapy for cocaine abuse. AAPS J 8: E196-E203.

Chen N, Reith MEA (2007). Substrates and inhibitors display different sensitivity to expression level of the dopamine transporter in heterologously expressing cells. J Neurochem 101: 377-388.

Chen R, Tilley MR, Wei H, Zhou F, Zhou F-M, Ching S et al (2006). Abolished cocaine reward in mice with a cocaine-insensitive dopamine transporter. Proc Natl Acad Sci USA 103: 9333-9338.

Chi L, Reith MEA (2003). Substrate-induced trafficking of the dopamine transporter in heterologously expressing cells and in rat striatal synaptosomal preparations. J Pharmacol Exp Ther 307: 729-736.

Daglish MR, Williams TM, Wilson SJ, Taylor LG, Eap CB, Augsburger $M$ et al (2008). Brain dopamine response in human opioid addiction. Br J Psychiatry 193: 65-72.

Daws LC, Callaghan PD, Morón JA, Kahlig KM, Shippenberg TS, Javitch JA et al (2002). Cocaine increases dopamine uptake and cell surface expression of dopamine transporters. Biochem Biophys Res Commun 290: 1545-1550. 
Desai RI, Kopajtic TA, Koffarnus M, Newman AH, Katz JL (2005). Identification of a dopamine transporter ligand that blocks the stimulant effects of cocaine. J Neurosci 25: 1889-1893.

Di Chiara G (1995). The role of dopamine in drug abuse viewed from the perspective of its role in motivation. Drug Alcohol Depend 38: 95-137.

Dole VP, Nyswander ME (1965). A medical treatment for diacetylmorphine (heroin) addiction: a clinical trial with methadone hydrochloride. JAMA 193: 646-650.

Dole VP, Nyswander ME, Kreek MJ (1966). Narcotic blockade. Arch Intern Med 118: 304-309.

Donny EC, Brasser SM, Bigelow GE, Stitzer ML, Walsh SL (2005). Methadone doses of $100 \mathrm{mg}$ or greater are more effective than lower doses at suppressing heroin self-administration in opioiddependent volunteers. Addiction 100: 1496-1509.

Donny EC, Walsh SL, Bigelow GE, Eissenberg T, Stitzer ML (2002). High-dose methadone produces superior opioid blockade and comparable withdrawal suppression to lower doses in opioiddependent humans. Psychopharmacology 161: 202-212.

Ferragud A, Velázquez-Sánchez C, Hernández-Rabaza V, Nácher A, Merino V, Cardá M et al (2009). A dopamine transport inhibitor with markedly low abuse liability suppresses cocaine self-administration in the rat. Psychopharmacology 207: 281-289.

Fiore MC, Jaén CR, Baker TB, Bailey WC, Benowitz NL et al (2008). Treating Tabacco Use and Dependence-Clinical Practice Guideline: 2008 Update (Agency for Health Care Research and Quality [AHRQ] Publication No. 08-0050-1). United States Department of Health and Human Services (U.S. Public Health Service): Rockville, Maryland.

Froimowitz M, Gu Y, Dakin LA, Nagafuji PM, Kelley CJ, Parrish D et al (2007). Slow-onset, long-duration, alkyl analogues of methylphenidate with enhanced selectivity for the dopamine transporter. J Med Chem 50: 219-232.

Froimowitz M, Wu K-M, Moussa A, Haidar RM, Jurayj J, George C et al (2000). Slow-onset, long-duration 3-( $3^{\prime}, 4^{\prime}$-dichlorophenyl)1 -indanamine monoamine reuptake blockers as potential medications to treat cocaine abuse. J Med Chem 43: 4981-4992.

Gardner EL (2000). What we have learned about addiction from animal models of drug self-administration. Am J Addict 9: $285-313$.

Gardner EL, Liu X, Paredes W, Giordano A, Spector J, Lepore M et al (2006). A slow-onset, long-duration indanamine monoamine reuptake inhibitor as a potential maintenance pharmacotherapy for psychostimulant abuse: effects in laboratory rat models relating to addiction. Neuropharmacology 51: 993-1003.

Glowa JR, Fantegrossi WE, Lewis DB, Matecka D, Rice KC, Rothman RB (1996). Sustained decrease in cocaine-maintained responding in rhesus monkeys with 1-[2-[bis(4-fluorophenyl)methoxy]ethyl]-4-(3-hydroxy-3-phenylpropyl) piperazinyl decanoate, a long-acting ester derivative of GBR 12909. J Med Chem 39: 4689-4691.

Grabowski J, Shearer J, Merrill J, Negus SS (2004). Agonist-like, replacement pharmacotherapy for stimulant abuse and dependence. Addict Behav 29: 1439-1464.

Howell LL, Wilcox KM (2001). The dopamine transporter and cocaine medication development: drug self-administration in nonhuman primates. J Pharmacol Exp Ther 298: 1-6.

Jones BE, Prada JA (1977). Effects of methadone and morphine maintenance on drug-seeking behavior in the dog. Psychopharmacology 54: 109-112.

Kahlig KM, Lute BJ, Wei Y, Loland CJ, Gether U, Javitch JA et al (2006). Regulation of dopamine transporter trafficking by intracellular amphetamine. Mol Pharmacol 70: 542-548.

Keith DE, Anton B, Murray SR, Zaki PA, Chu PC, Lissin DV et al (1998). $\mu$-Opioid receptor internalization: opiate drugs have differential effects on a conserved endocytic mechanism in vitro and in the mammalian brain. Mol Pharmacol 53: 377-384.
Koob GF, Ahmed SH, Boutrel B, Chen SA, Kenny PJ, Markou A et al (2004). Neurobiological mechanisms in the transition from drug use to drug dependence. Neurosci Biobehav Rev 27: 739-749.

Koob GF, Le HT, Creese I (1987). The $\mathrm{D}_{1}$ dopamine receptor antagonist SCH 23390 increases cocaine self-administration in the rat. Neurosci Lett 79: 315-320.

Kozlowski LT, Giovino GA, Edwards B, Difranza J, Foulds J, Hurt R et al (2007). Advice on using over-the-counter nicotine replacement therapy-patch, gum, or lozenge-to quit smoking. Addict Behav 32: 2140-2150.

Kramer HK, Simon EJ (1999). Role of protein kinase C (PKC) in agonist-induced $\mu$-opioid receptor down-regulation: $\mathrm{I}$. PKC translocation to the membrane of SH-SY5Y neuroblastoma cells is induced by $\mu$-opioid agonists. $J$ Neurochem 72: 585-593.

Kreek MJ (2000). Methadone-related opioid agonist pharmacotherapy for heroin addiction. History, recent molecular and neurochemical research and future in mainstream medicine. Ann NY Acad Sci 909: 186-216.

Kuhar MJ, Pilotte NS (1996). Neurochemical changes in cocaine withdrawal. Trends Pharmacol Sci 17: 260-264.

Lepore M, Franklin KBJ (1992). Modeling drug kinetics with brain stimulation: dopamine antagonists increase self-stimulation. Pharmacol Biochem Behav 41: 489-496.

Leri F, Tremblay A, Sorge RE, Stewart J (2004). Methadone maintenance reduces heroin- and cocaine-induced relapse without affecting stress-induced relapse in a rodent model of poly-drug use. Neuropsychopharmacology 29: 1312-1320.

LeSage MG, Stafford D, Glowa JR (1999). Preclinical research on cocaine self-administration: environmental determinants and their interaction with pharmacological treatment. Neurosci Biobehav Rev 23: 717-741.

Little KY, Elmer LW, Zhong H, Scheys JO, Zhang L (2002). Cocaine induction of dopamine transporter trafficking to the plasma membrane. Mol Pharmacol 61: 436-445.

Loder MK, Melikian HE (2003). The dopamine transporter constitutively internalizes and recycles in a protein kinase Cregulated manner in stably transfected PC12 cell lines. J Biol Chem 278: 22168-22174.

Loland CJ, Desai RI, Zou M-F, Cao J, Grundt P, Gerstbrein K et al (2008). Relationship between conformational changes in the dopamine transporter and cocaine-like subjective effects of uptake inhibitors. Mol Pharmacol 73: 813-823.

Mayfield RD, Zahniser NR (2001). Dopamine D2 receptor regulation of the dopamine transporter expressed in Xenopus laevis oocytes is voltage-independent. Mol Pharmacol 59: 113-121.

Newman AH, Kulkarni S (2002). Probes for the dopamine transporter: new leads toward a cocaine-abuse therapeutic-A focus on analogues of benztropine and rimcazole. Med Res Rev 22: 429-464.

O'Brien CP (1997). A range of research-based pharmacotherapies for addiction. Science 278: 66-70.

Oldendorf WH (1992). Some relationships between addiction and drug delivery to the brain. NIDA Res Monogr 120: 13-25.

Patel MB, Patel CN, Rajashekara V, Yoburn BC (2002). Opioid agonists differentially regulate $\mu$-opioid receptors and trafficking proteins in vivo. Mol Pharmacol 62: 1464-1470.

Paxinos G, Watson C (1998). The Rat Brain in Stereotaxic Coordinates, 4th edn. Academic Press: Sydney.

Platt DM, Rowlett JK, Spealman RD (2002). Behavioral effects of cocaine and dopaminergic strategies for preclinical medication development. Psychopharmacology 163: 265-282.

Reith MEA, Berfield JL, Wang LC, Ferrer JV, Javitch JA (2001). The uptake inhibitors cocaine and benztropine differentially alter the conformation of the human dopamine transporter. J Biol Chem 31: 29012-29018. 
Rothman RB, Baumann MH, Prisinzano TE, Newman AH (2008). Dopamine transport inhibitors based on GBR12909 and benztropine as potential medications to treat cocaine addiction. Biochem Pharmacol 75: 2-16.

Rothman RB, Glowa JR (1995). A review of the effects of dopaminergic agents on humans, animals, and drug-seeking behavior, and its implications for medication development. Focus on GBR 12909. Mol Neurobiol 11: 1-19.

Runyon SP, Carroll FI (2006). Dopamine transporter ligands: recent developments and therapeutic potential. Curr Top Med Chem 6: 1825-1843.

Saunders C, Ferrer JV, Shi L, Chen J, Merrill G, Lamb ME et al (2000). Amphetamine-induced loss of human dopamine transporter activity: an internalization-dependent and cocainesensitive mechanism. Proc Natl Acad Sci USA 97: 6850-6855.

Spiller K, Xi Z-X, Peng X-Q, Newman AH, Ashby Jr CR, Heidbreder $C$ et al (2008). The selective dopamine $\mathrm{D}_{3}$ receptor antagonists SB-277011A and NGB 2904 and the putative partial $\mathrm{D}_{3}$ receptor agonist BP-897 attenuate methamphetamine-enhanced brain stimulation reward in rats. Psychopharmacology 196: $533-542$.

Veilleux JC, Colvin PJ, Anderson J, York C, Heinz AJ (2010). A review of opioid dependence treatment: pharmacological and psychosocial interventions to treat opioid addiction. Clin Psychol Rev 30: 155-166.

Volkow ND, Ding Y-S, Fowler JS, Wang G-J, Logan J, Gatley JS et al (1995). Is methylphenidate like cocaine? Studies on their pharmacokinetics and distribution in the human brain. Arch Gen Psychiatry 52: 456-463.

Welch WM, Kraska AR, Sarges R, Koe BK (1984). Nontricyclic antidepressant agents derived from cis- and trans-1-amino-4aryltetralins. J Med Chem 27: 1508-1515.

Wise RA (1996). Neurobiology of addiction. Curr Opin Neurobiol 6: $243-251$.
Wise RA, Gardner EL (2004). Animal models of addiction. In: Charney DS, Nestler EJ (eds). Neurobiology of Mental Illness, 2nd edn, Oxford University Press: London. pp 683-697.

Woolverton WL, Wang Z (2004). Relationship between injection duration, transporter occupancy and reinforcing strength of cocaine. Eur J Pharmacol 486: 251-257.

Xi Z-X, Gilbert JG, Pak AC, Ashby Jr CR, Heidbreder CA, Gardner EL (2005). Selective dopamine $\mathrm{D}_{3}$ receptor antagonism by SB$277011 \mathrm{~A}$ attenuates cocaine reinforcement as assessed by progressive-ratio and variable-cost-variable-payoff fixed-ratio cocaine self-administration in rats. Eur $J$ Neurosci 21: 3427-3438.

Xi Z-X, Li X, Peng X-Q, Li J, Chun L, Gardner EL et al (2010). Inhibition of NAALADase by 2-PMPA attenuates cocaineinduced relapse in rats: a NAAG-mGluR2/3-mediated mechanism. J Neurochem 112: 564-576.

Xi Z-X, Newman AH, Gilbert JG, Pak AC, Peng X-Q, Ashby Jr CR et al (2006). The novel dopamine $\mathrm{D}_{3}$ receptor antagonist NGB 2904 inhibits cocaine's rewarding effects and cocaine-induced reinstatement of drug-seeking behavior in rats. Neuropsychopharmacology 31: 1393-1405.

Xi Z-X, Ramamoorthy S, Shen H, Lake R, Samuvel DJ, Kalivas PW (2003). GABA transmission in the nucleus accumbens is altered after withdrawal from repeated cocaine. J Neurosci 23: 3498-3505.

Xi Z-X, Stein EA (2002). GABAergic mechanisms of opiate reinforcement. Alcohol Alcohol 37: 485-494.

Zahniser NR, Sorkin A (2004). Rapid regulation of the dopamine transporter: role in stimulant addiction? Neuropharmacology 47(Suppl 1): 80-91.

Zapata A, Kivell B, Han Y, Javitch JA, Bolan EA, Kuraguntla D et al (2007). Regulation of dopamine transporter function and cell surface expression by D3 dopamine receptors. J Biol Chem 282: 35842-35854. 